\title{
Analysis on the Status of Innovation and Entrepreneurship Education for Private College Students
}

\author{
Zhou Hong \\ Changsha Medical University, Changsha Wangcheng, Changsha, Hunan, China, 410219
}

Keywords: private colleges and universities; innovation and entrepreneurship; education

\begin{abstract}
Under the current employment situation, it has become an inevitable trend for university education to carry out innovation and entrepreneurship in a comprehensive way. College students should set up innovative consciousness and entrepreneurship, master the basic knowledge and practical skills needed for innovation and entrepreneurship, and enhance their entrepreneurial ability. It is of particular importance to both society and individuals. At present, due to the preference of the talent market to public colleges and universities, the employment pressure of private colleges and universities has increased dramatically. Many private colleges and universities have responded to the call of the state, and began to try to conduct innovations for students. It is hoped to promote employment through innovation and entrepreneurship to alleviate employment pressure, so as to enhance the core competitiveness of private colleges and universities. However, because many private colleges and universities have the knowledge and practice deviation of innovation and entrepreneurship education, the innovation and entrepreneurship education fails to play its due function.
\end{abstract}

\section{Introduction}

On May 13, 2015, the general office of the state council released the opinions on the implementation of education reform of innovation and entrepreneurship in institutions of higher learning. We will further promote the comprehensive reform of education in China and promote higher quality and entrepreneurship employment for college graduates. In recent years, universities have paid more and more attention to the innovation and entrepreneurship of college students. It can be seen that the innovation and entrepreneurship education of college students has become an important part of the national innovation-driven development strategy. At the same time, to build an innovation-oriented country is inseparable from the cultivation of talents with certain innovative abilities. Now universities are trying to integrate innovation and entrepreneurship education into students' talent training. In order to cultivate innovative talents with certain innovative consciousness, innovative thinking and entrepreneurial ideas. Innovation and entrepreneurship education is highly valued because of its economic value. Private colleges and universities themselves are inferior to public colleges and universities, and employers will give preference to graduates of public schools when recruiting. Moreover, the enrollment of private colleges and universities is limited compared with that of the public universities, and the entrance examination scores of students are far lower than that of public schools. Some students are not active in school, lack of theoretical knowledge and lack of professional skills, which leads to the difficulty of employment for private college students.

\section{The Significance of Innovation and Entrepreneurship Education in Private Colleges and Universities}

\subsection{Promote the development of private colleges and universities}

The expansion of colleges and universities has led to great pressure on the graduates of private colleges and universities. After graduation, self-employment has become a new way to realize employment. However, compared with public institutions, private colleges have short running time 
and lack of experience. Moreover, some schools have not yet established perfect training and experimental conditions for lack of funds, so it is difficult for students to meet the needs of enterprises after graduation. At present, the society does not fully recognize the ability of private college graduates, which leads to the difficulty of recruiting students and the vicious circle of more difficult graduates' employment. In order to improve the influence of private universities and solve the problem of graduates' difficult employment, the school must carry out comprehensive and high-quality innovation and entrepreneurship education. The real meaning is not to let every student start a company, but to cultivate students' awareness and spirit of innovation and entrepreneurship. In this way, we can not only reserve a large number of innovative talents for our country's development, but also greatly enhance the influence of private colleges and universities. Although this process is relatively long, private colleges and universities must take the long-term consideration and seize the opportunity to develop the innovation and entrepreneurship of the university. The development of innovation and entrepreneurship education is the embodiment of the transformation of our traditional educational philosophy. It is one of the important factors to measure the teaching quality and teaching level, and also the main way to relieve the pressure of employment in China. Innovation and entrepreneurship education not only can greatly reduce the pressure of employment of private college graduates, but also has great significance for the survival and healthy development of private colleges and universities.

\subsection{Promote the core competitiveness of private colleges and universities}

The future competition of colleges and universities mainly depends on how many excellent students are recognized by the society. At present, China's innovation and entrepreneurship education is still in the experimental and initial stage. China's ministry of education pilot job is to carry out the innovation of entrepreneurship education grope for how to carry out quality education in our country, to further promote the work in institutions of higher learning education from exam-oriented education to quality education. This can make colleges and universities pay more attention to the cultivation of students' innovation and entrepreneurship awareness and ability, so as to provide better human resources for the society. Since China's ministry of education wants to expand the scale of education, promote the elite education to the popular education. Therefore, our private colleges and universities should have a correct orientation in the future development, try to seize all the opportunities, and create the distinctive education of private colleges and universities. Although China's private colleges and universities occupy a place in the whole country, they should continue to maintain the competitive advantage. We must further reform education mode, improve education level and focus on innovation and entrepreneurship education. We will encourage graduates from private colleges to start their own businesses, improve students' employability, and cultivate more talents to meet the needs of social development. Only in this way can we improve the influence of private colleges and universities in society, and then improve the level of private colleges in China. At the same time, entrepreneurship can also promote the economic development of the local and the whole country, and promote social harmony. Through innovation and entrepreneurship education, private colleges and universities can realize the transformation of university function and mission, and greatly improve their core competence.

\subsection{Promote the self-development of college students in private colleges and universities}

Innovation and entrepreneurship education is mainly carried out to enhance the graduates' ability of employment and entrepreneurship. The improvement of creativity and entrepreneurial ability of private colleges and universities has become the basic responsibility of education in private colleges and universities. How can we make ourselves more competitive in the process of employment, and improve the innovation ability of college students themselves? Only in private colleges and universities to carry out innovation and entrepreneurship education. However, due to the shackles of traditional employment thought, graduates generally lack the consciousness of self-employment. However, under the current severe employment situation, not all college students can achieve employment smoothly. In particular, the college students in private colleges and universities are less influential than public schools and have low employment competitiveness. Innovation and 
entrepreneurship education can provide students with the opportunity to exercise business savvy and realize the value of life. In the most active university stage of life, it can bring entrepreneurial passion and creativity to make college students become an important engine driving economic development.

\section{Problems of Innovation and Entrepreneurship Education in Private Colleges and Universities}

\subsection{Students' weal awareness of innovation and entrepreneurship education}

The students of private colleges and universities are two or three special starting points. Generally speaking, we are still very concerned about the future development and lack of sense of identity for our school. Students themselves lack confidence, information lag, blind action and design planning, and poor execution. Some students have a good family condition and a high starting point; Some students have financial difficulties and pressure: more students lack goals and follow up blindly. Most private college students want to learn about entrepreneurship, but they do not plan to start their own business. But to prepare for the future is the second option for unsuccessful employment. Therefore, students' awareness of innovation and entrepreneurship education is relatively weak.

\subsection{The single form of innovation and entrepreneurship education}

At present, many colleges and universities offer innovation and entrepreneurship education courses for all students, but more are just theoretical and lack practical experience. Students of finance related majors in private colleges and universities are highly motivated in innovation and entrepreneurship, while the enthusiasm of other professional students to participate in innovation and entrepreneurship activities is very low. On the one hand, students lack understanding of innovation and entrepreneurship; On the other hand, even if students participate in innovation and entrepreneurship programs, they tend to have a low starting point and simple form.

\subsection{Weak innovation and entrepreneurship teachers}

At present, it is necessary to have a team with innovative entrepreneurial consciousness and innovative thinking, which is very important for guiding teachers' guidance. However, most of the teachers currently engaged in innovation and entrepreneurship in colleges and universities do not have the practical experience of innovation and entrepreneurship, and only stay on the theoretical level. At present, there is no way to spare time to learn and improve the innovative ideas and innovative thinking of the teachers in colleges and universities. This leads students to focus only on professional knowledge while learning theoretical knowledge, while studying innovation and entrepreneurship theory courses only focus on the examples given by teachers. Students lack the awareness to think about how to innovate, and can't integrate professional theoretical knowledge with innovation and entrepreneurship.

\section{Countermeasures of Innovation and Entrepreneurship Education in Private Colleges and Universities}

\subsection{Enhance the awareness of innovation and entrepreneurship education for college students}

The innovation and entrepreneurship consciousness is an important factor that students should have in innovation and entrepreneurship, which influences students' specific behaviors and attitudes towards entrepreneurship. Therefore, private colleges and universities should enhance the innovation and entrepreneurship consciousness of college students. We will continue to explore the law of cultivating entrepreneurial talents, and actively carry out the reform of personnel training mode. The innovation and entrepreneurship education infiltrated into the education teaching reform of the school through the whole process of personnel training. Formation to help college students to come in all kinds of specific transaction for the purpose, as the key to enhance college students' 
entrepreneurial ability and consciousness, to train college students' entrepreneurial spirit and interests as the core of innovation entrepreneurship education new ideas. At the same time, we should actively promote the wide publicity of innovation and entrepreneurship education. We will promote the independent innovation and entrepreneurship of college students and the content of education to create a positive social environment for college students. Use the Internet, radio, books, newspapers and other news media, to be state and local governments in the area of college students' entrepreneurship preferential policies and convenient measures, to actively promote entrepreneurial success of college students. These college students who have succeeded in starting their own business have come out to talk about it, or have a lecture tour to cultivate their passion for entrepreneurship. Establish the right concept of success, employment and entrepreneurship. Open a theme column in the school newspaper, publicize innovation and entrepreneurship education. We should expand the social influence of innovation and entrepreneurship education, and enhance students' awareness of innovation and entrepreneurship.

\subsection{Construct innovation and entrepreneurship education faculty team}

The premise of cultivating students' innovative entrepreneurial spirit and ability is that their teachers must have good entrepreneurial spirit and entrepreneurial ability. Only after the teacher has a certain sense of entrepreneurship, can teachers further extract the training content of education from social practice and school textbooks. It is only possible to integrate entrepreneurial ideas into daily teaching activities, and actually implement innovation and entrepreneurship education into each course. We should further cultivate students' innovative spirit and entrepreneurial consciousness, and promote students to form a more complete innovation and entrepreneurship quality. Therefore, it is necessary for teachers to keep abreast of the progress of society and the development of The Times, to extract information from all aspects, to understand, learn and master the teaching methods in a timely manner. We have the courage to renovate the teaching curriculum and teaching plan, so that the school can truly provide better human resources for the society and the country. Therefore, it is necessary to carry out the systematic and professional training of the school teachers, introduce high-quality entrepreneurial education teachers resources, and then establish a higher level of entrepreneurial teachers' team.

\subsection{Actively carry out quality development activities}

Private colleges and universities should take scientific research training program as the carrier and actively guide students to participate in the research on scientific research. Organize and guide students to carry out scientific research activities and strengthen the cultivation of students' innovative thinking, methods and abilities. At the same time, actively organize the students' science and technology innovation festival, the second class of science and technology cultural activities. We will support and strengthen the construction of innovative entrepreneurial students' organizations, and guide the innovation and entrepreneurship communities of college students to carry out series activities such as entrepreneurship salon, and cultivate the team consciousness of college students. Innovation and entrepreneurship BBS, invite well-known entrepreneurs, educators and our school successful entrepreneurial students, successful alumni to participate in BBS. We will comprehensively strengthen social practice activities such as college students' social investigation, enrich students' innovative entrepreneurial knowledge and experience, and promote students to be exposed to education, talent and contribution in the social class.

\section{Conclusion}

At present, innovation and entrepreneurship education still exist in colleges and universities. Education and professional knowledge are separated from each other. The school education practice platform is not perfect, the innovation and entrepreneurship mentor team is relatively weak. In the future education process, we should strengthen the integration of education with innovation and entrepreneurship education. Private colleges and universities should create a curriculum for creative integration and promote education teaching level, which is a continuous and stable development of 
university student innovation and entrepreneurship education.

\section{References}

[1] Busenitz L W. West III G P, et a1. Entrepreneurship Research in Emergence: Past Trends and Future Directions. Journal of Management (2003) pp 285 - 308

[2] Shane. Venkataraman. Macmillan 2005 Cultural differences in innovation championing strategies. Manage (2005) pp 931-953

[3] Belinda Luke, Martie Louise Verreynne, Kate Kearins. Innovative and entrepreneurial activity in the public sector: The changing face of public sector institutions. Innovation (2010) pp 138 - 153

[4] Potter J. Entrepreneurship and Higher Education: Future Policy Directions. Sourceoecd Education \& Skills volume (2013), p. 422 - 448

[5] Shanes. Prior Knowledge and the Discovery of Entrepreneurial Opportunities. Organization Science (2010), p. 448 - 469

[6] Bull I, GE Willard. Towards a theory of entrepreneurship. Journal of Bussiness Venturing (1993), p. 183 - 195

[7] PITT A, LEYLAND F. RUSHIEDA $k$ The Role of Adapuaioll in Microenterprise Development: A Marketing Perspective. Journal of International Development (2000), p. 803 - 820 